\title{
Identification of Energy Efficiency Trends in the Context of the Development of Industry 4.0 Using the Polish Steel Sector as an Example
}

\author{
Radosław Wolniak ${ }^{1, *(\mathbb{D})}$, Sebastian Saniuk ${ }^{2} \mathbb{D}$, Sandra Grabowska ${ }^{3, *(\mathbb{D}}$ and Bożena Gajdzik ${ }^{4}$ \\ 1 Department Economy and Informatics, Silesian University of Technology, 41-800 Zabrze, Poland \\ 2 Department of Engineering Management and Logistics Systems, University of Zielona Gora, \\ 65-246 Zielona Gora, Poland; s.saniuk@wez.uz.zgora.pl \\ 3 Department of Production Engineering, Silesian University of Technology, 40-019 Katowice, Poland \\ 4 Department of Industrial Informatics, Silesian University of Technology, 40-019 Katowice, Poland; \\ bozena.gajdzik@polsl.pl \\ * Correspondence: radoslaw.wolniak@polsl.pl (R.W.); sandra.grabowska@polsl.pl (S.G.); \\ Tel.: +48-32-6034341 (S.G.)
}

Received: 30 April 2020; Accepted: 27 May 2020; Published: 4 June 2020

\begin{abstract}
The steel sector is crucial for the national economy of Poland and the global economy. In response to the challenges of the global steel market and the need to increase the sector's competitiveness, a number of actions have been taken to increase the energy efficiency of steel production. Based on the synthesis of the literature and our own research, we describe the issues related to energy efficiency and the Industry 4.0 concept. The main aim of this paper is to identify energy efficiency trends in enterprises, especially those that focus on increasing the energy efficiency of production processes, and to make recommendations for investment policy for the Polish steel sector in the era of Industry 4.0. To achieve our goals and answer the research question, we used data from 2000-2019 for the Polish steel industry. The calculations and models in this paper were made by using Gretl software. Using direct research, an econometric model was built that verified the hypothesis regarding the relationship between investment in new technologies and the energy efficiency of steel production. Future investment policies should take the implementation of Industry 4.0 tools in the steel sector into account, which, according to the authors, will measurably improve energy efficiency.
\end{abstract}

Keywords: energy efficiency; Industry 4.0; investment policy in the steel sector

\section{Introduction}

Although the Polish steel sector is one of the most modern in Europe, it requires support to ensure its international competitiveness and sustainable development. One of the key challenges of the modern global economy is to reduce environmental pollution and save limited natural resources. Therefore, more and more industries are trying to use energy more efficiently. This is due to market pressure, public awareness of the need for sustainable development of the economy, rising energy costs and environmental vulnerability. Energy efficiency is one of the most important and cost-effective means by which industry can reduce its greenhouse gas emissions for sustainable development and lower its production costs [1,2]. Thus, there is a need for changes in production processes and for economical technologies and production processes that are aimed at the efficient use of natural resources and energy. Excessive energy consumption in production processes is one of the key reasons for environmental pollution, including $\mathrm{CO}_{2}$ emissions. 
The current implementation of the Industry 4.0 concept, which is oriented towards energy efficiency and improving customer service, provides an opportunity for changes in resource and energy efficiency in the steel sector. The innovative solutions offered by Industry 4.0 focus on the efficient customization of production and flexibility, which on the one hand, significantly increase the added value of the business, and on the other hand, reduce business costs. The main advantage of flexibility is that it allows changes in the production process to be implemented as quickly as possible, with optimal equipment performance and optimal use of resources to better meet customer needs [3-6].

The Industry 4.0 concept provides the prerequisites for achieving sustainable production using modern information and communication technologies (ICT). A greater level of customization of production, the construction of smart factories and the networking of the economy are intended to help to manage resources more economically, including energy. Better adaptation of production to demand (consumer requirements) and the use of smart technologies in production and logistics reduces waste in various areas of activity (including unnecessary transport, failures, defective products, high operating costs, etc.) $[7,8]$.

Industry 4.0 contributes to the efficiency of industrial installations, reduces their energy consumption and increases the energy efficiency of industrial processes, including the steel sector, through intelligent machine control and management. The development of digitization and computer technology linked to the implementation of the Industry 4.0 concept, makes it possible to equip cyber-physical production and logistics systems with measuring instruments and digital devices to continuously monitor many aspects of machine (object) operation and its environment [9-14]. This allows the results to be produced automatically and compared with accepted levels (including energy consumption and energy management). One of the most energy-intensive production sectors with great potential for reducing energy demand is iron and steel production $[7,15]$. This industry has one of the highest levels of carbon emissions and energy consumption in Europe, and at the same time, it is of great economic importance for the European Union [10].

Industry 4.0 could have major benefits for the European iron and steel industry as it evolves through to 2030, with a strong positive effect on process efficiency. Implementation of the Industry 4.0 concept will open up opportunities to develop new business models and will lead to more efficient interactions between customers and suppliers. Improvements in product are also expected but will be less pronounced than improvements in process efficiency. Substantial reductions in energy demand and related emissions are also expected [11].

Climate change, the threat of energy insecurity and rising energy prices are intensifying the need to improve energy efficiency in the steel sector. According to Johansson, the gap in energy efficiency in this sector is well known but cost-effective solutions are rarely put into practice. This is due to a long payback period, lack of profitability and organizational barriers such as lack of appropriate staff, lack of knowledge and management incompetence, risk of production disruptions, lack of time and lack of commitment among employees [16].

Implementing Industry 4.0 can be subject to various barriers. Many different technical barriers exist and that these are of nearly equal importance. These include concerns about reliability, safety and security, about technical compatibility and the alignment of entire systems, and about the availability of suitable production hardware and software. In their study, the authors also emphasized the importance of organizational barriers, including the lack of qualified personnel, the possibility of short payback, as well as uncertainty or missing information on the economic benefits of using Industry 4.0 [17].

In the Polish economy, the steel sector needs investment in new technology for better data gathering to make use of Big Data analysis and to use data in the decision-making process. In the foundry industry, there is also a need for data mining technology. This means that the currently used methods of manual control can be replaced by new, automated decision-making systems [18-25]. Industry 4.0 is currently being discussed extensively by politicians, scientists and entrepreneurs in many sectors, including the steel sector. The Industry 4.0 concept was developed in 2011 and presented as part of the German High-Tech Strategy in 2020. Industry 4.0 is based on the development of the automation and robotization 
of production, which was a pillar of the Third Industrial Revolution [13,26]. Although Industry 4.0 is a hotly debated topic, its consequences for the steel industry have still not been examined. Currently, the main implementation of the Industry 4.0 concept in the steel sector has been investment in new technology for improving the efficiency of steel production and energy efficiency [27]. The pillars of the Fourth Industrial Revolution are modern technologies, such as the Internet of Things (IoT), Big Data and data analytics, cloud and fog computing, advanced simulation, autonomous systems, universal integration, augmented reality (AR), artificial intelligence (AI), automated production simulation and additive manufacturing (AM) with learning machines and smart robots, and integrated smart products $[13,28]$. Figure 1 presents a simplified scope for the analysis of energy efficiency in the Industry 4.0 environment.

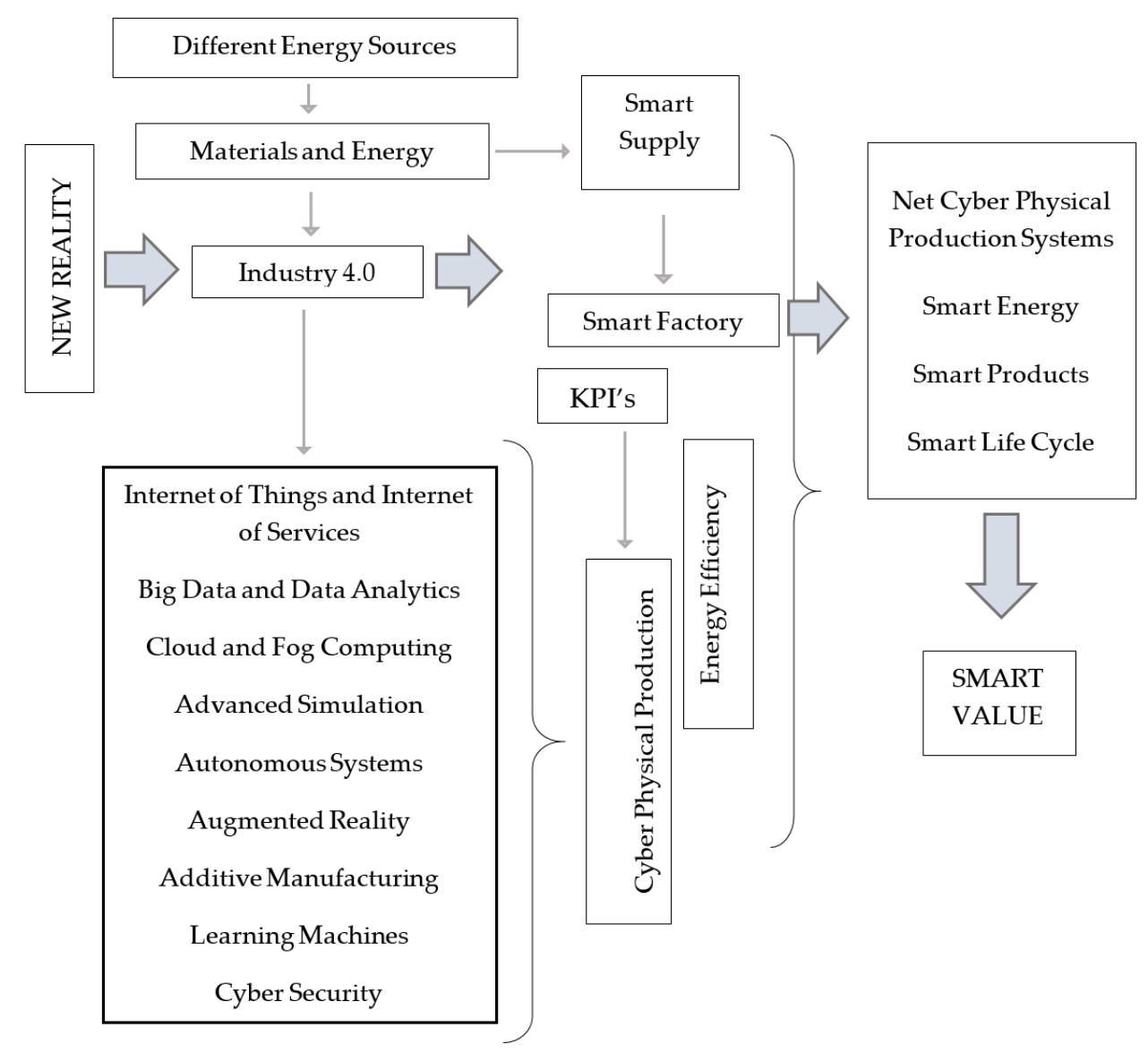

Figure 1. Industrial space and environment 4.0 for energy efficiency.

All attributes of Industry 4.0 can be used in energy efficiency management in the steel sector. Energy reduction can be achieved through active monitoring of energy consumption and an intelligent energy management system. A systems approach to energy efficiency management in and outside the production facilities (layout, energy producer, supplier, user) is required. Essentially, this approach involves increasing the share of renewable energy in total energy consumption and improving the energy efficiency in the network of energy producers and users with a significant diversification of energy sources [29-34].

On the basis of an analysis of the literature [18-24,35-49], we found that there was a gap in the literature regarding the effectiveness of new investments connected with Industry 4.0 and the energy consumption of the steel production process. Many studies have analyzed the technical aspects of Industry 4.0 implementation but analyses of the economic aspects are rare. This is an important issue 
that needs to be considered more fully as it highlights the need for new investments in Industry 4.0 technologies that will improve the productivity of production and energy efficiency.

Hence, there is a need for research on developing investment policies aimed at increasing energy efficiency in the steel industry. This article attempts to determine the main trends related to investments in new technologies connected with Industry 4.0 and to examine their impact on energy efficiency in the Polish steel sector under the conditions of the implementation of the Industry 4.0 concept.

The main aim of the paper is the identification of energy efficiency trends in enterprises aimed at increasing the energy efficiency of implemented production processes and defining recommendations for investment policy for the Polish steel sector in the era of Industry 4.0.The following hypothesis was adopted: the value of energy consumption (energy consumption per one tonne of steel production) will decrease in the long term as a result of investments in new technologies in the Polish steel industry.

An important contribution to this work is the answer to the question of whether there is a relationship between investments in new technologies (including recent technologies related to automation and Industry 4.0) and reducing energy consumption to produce one tonne of steel. Currently, investment in the Polish steel sector is mainly related to the implementation of Industry 4.0 technologies and focuses mainly on the automation of steel production, the widespread use of the Internet of Things and the analysis of large data sets.

\section{Materials and Methods}

In this study, we carried out an analysis of secondary data, which is presented in Table 1 . The key data were:

- energy consumption per one tonne of steel production in Poland

- the volume of investments in the steel industry in Poland.

Table 1. Values of energy consumption per one tonne of steel production and the value of investment in new technologies in the years 2000-2019.

\begin{tabular}{|c|c|c|c|c|c|c|}
\hline \multirow{2}{*}{$\begin{array}{l}0 \\
0 \\
0 \\
0 \\
0 \\
0 \\
0 \\
0 \\
0\end{array}$} & \multirow{2}{*}{ Year } & $\begin{array}{l}\text { Energy Consumption per } \\
1 \text { Tonne of Steel in Poland }\end{array}$ & $\begin{array}{l}\text { Total Investments } \\
\text { (in Reality) }\end{array}$ & $\begin{array}{l}\text { Total Investments by } \\
\text { Used Methodology }\end{array}$ & $\begin{array}{l}\text { Fixed Prices } \\
\text { Index }\end{array}$ & $\begin{array}{c}\text { Discounted } \\
\text { Investment Value }\end{array}$ \\
\hline & & Toe & PLN Million & PLN Million & $\begin{array}{c}\text { Year } \\
2000=100\end{array}$ & PLN Million \\
\hline 1 & 2000 & 0.3290 & 400 & 137 & 100 & 137.0 \\
\hline 2 & 2001 & 0.3280 & 230 & 137 & 100.5 & 129.9 \\
\hline 3 & 2002 & 0.3000 & 160 & 137 & 107.5 & 127.4 \\
\hline 4 & 2003 & 0.2900 & 170 & 137 & 108.4 & 126.4 \\
\hline 5 & 2004 & 0.2810 & 137 & 528 & 112.2 & 470.6 \\
\hline 6 & 2005 & 0.2730 & 528 & 1511 & 114.6 & 1318.5 \\
\hline 7 & 2006 & 0.2500 & 1511 & 2022 & 115.7 & 1747.6 \\
\hline 8 & 2007 & 0.2220 & 2022 & 1994 & 118.6 & 1681.3 \\
\hline 9 & 2008 & 0.2080 & 1994 & 1694 & 123.6 & 1370.6 \\
\hline 10 & 2009 & 0.1950 & 1694 & 484 & 127.9 & 378.4 \\
\hline 11 & 2010 & 0.1960 & 484 & 699 & 131.2 & 532.8 \\
\hline 12 & 2011 & 0.1950 & 699 & 602 & 136.8 & 440.1 \\
\hline 13 & 2012 & 0.2050 & 602 & 575 & 141.9 & 405.2 \\
\hline 14 & 2013 & 0.2080 & 575 & 550 & 143.2 & 384.1 \\
\hline 15 & 2014 & 0.1970 & 550 & 650 & 143.2 & 453.9 \\
\hline 16 & 2015 & 0.1880 & 650 & 830 & 141.9 & 584.9 \\
\hline 17 & 2016 & 0.1970 & 830 & 530 & 141 & 375.9 \\
\hline 18 & 2017 & 0.1920 & 530 & 870 & 143.8 & 605.0 \\
\hline 19 & 2018 & 0.1935 & 870 & 870 & 146.1 & 595.5 \\
\hline 20 & 2019 & 0.1923 & 350 & 870 & 149.5 & 581.9 \\
\hline
\end{tabular}

The statistical data presented in Table 1 comes from the Polish Steel Association in Katowice, Poland and the Central Statistical Office. The data is presented in time series for the period $(t=20)$ from 2000 to 2019. This period relates to an important period for the steel sector as it follows the transformation of the Polish economy from a centrally controlled economy to a market economy. The size of investments was expressed in monetary units and the value of the investments was realized 
by using the GDP (gross domestic product) deflator. The year 2000 was assumed to be $100 \%$ for the fixed price index (column 5 in Table 1).

Here, the main technologies considered as investments in the steel industry are referred to as advanced energy management systems and best available technique (BAT) technologies. Solutions used in the Polish steel industry as part of BAT technology along with the development of the Industry 4.0 concept include, among others devices for optical control of rolled profile diameters on-line, laser distance measurement (LDM) sensors for measuring the diameter and width of metal plates, infrared (Rota-Sonde) for detecting and controlling the position of hot products, triangulation scanning (Trilas TL) and time-of-flight tests (Dilas FT) for measuring distance and dimensions, stereoscopic imaging (DigiScan) for measuring width and image processing (CropVision) for optimizing cropping, etc.

To achieve the aim of the study and verify the research hypothesis, a literature synthesis and statistical methods were used. Correlation and regression analysis was performed and an econometric model was built, according to literature [50-52]. The research methodology is shown in Figure 2.

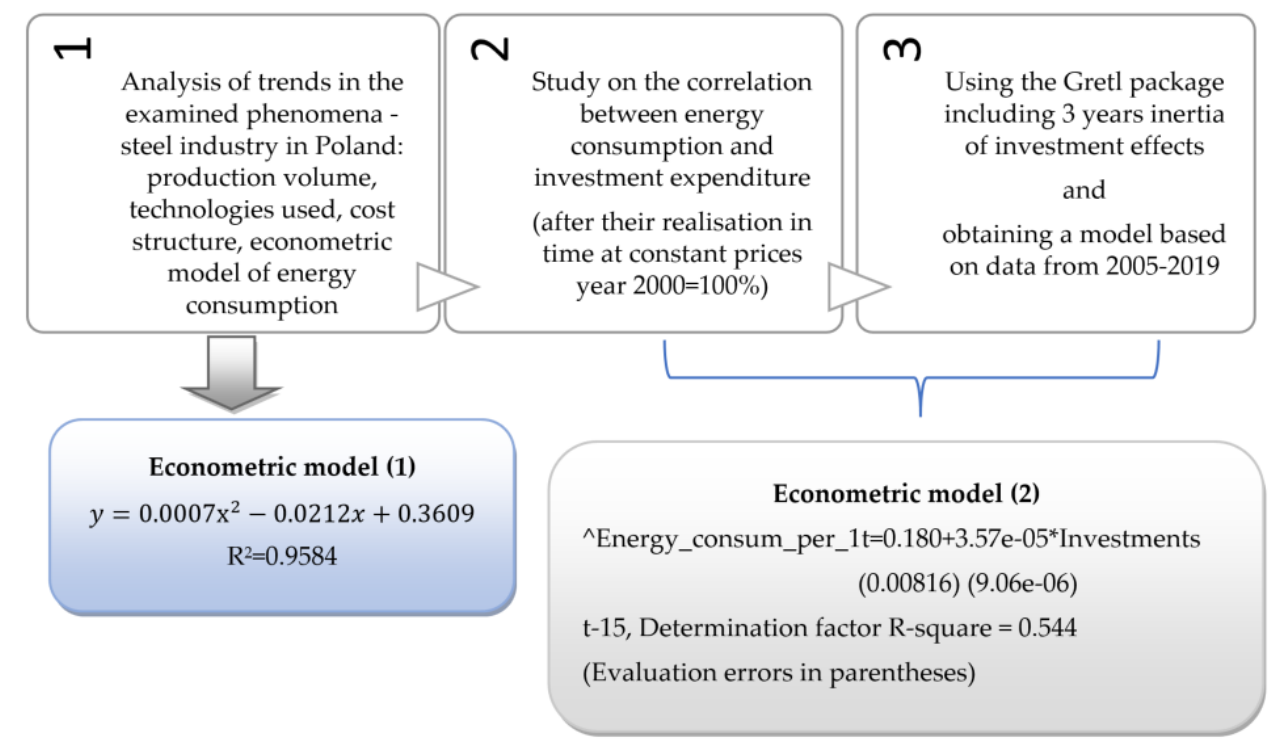

Figure 2. Research methodology.

The strength of the relationship between the studied variables was measured using Pearson's correlation coefficient [50].

$$
r=\frac{\operatorname{cov}(x, y)}{s(x) * s(y)}
$$

where $x$ is the energy consumption value for the production of a 1 tonne of steel and $y$ is the value of the investment.

The Pearson's correlation coefficient is a basic research tool for studying the relationship between two variables [50]. The rationale for the selection of the Pearson's correlation coefficient resulted from the assumed hypothesis (scope of research), which is based on two interdependent variables: electricity consumption per one tonne of steel and investment expenditure, and this dependence determines further changes in the studied sector as a result of Industry 4.0.

It was assumed that the investments made in the analyzed period from 2000 to 2019 in the steel industry in Poland involved automation of production, robotization of sections of technological lines, and instrumentation of the machine park with sensors and other equipment for real-time data transmission and measurement of productivity indicators. The Pearson's correlation coefficient used for the analysis is a form of standardized covariance. The calculations and models in this paper were 
made by using Gretl software. The Gretl is an open source statistical software that is mainly used for econometric purposes [53].

\section{Results}

The steel industry is very energy intensive. The costs of material and energy consumption account for about $64 \%$ of total production costs (Figure 3), other costs are: about $15 \%$ for employee wages and employee benefits, $12 \%$ for external services, $5 \%$ for depreciation, and $4 \%$ are other costs $[54,55]$ (see Figure 3).

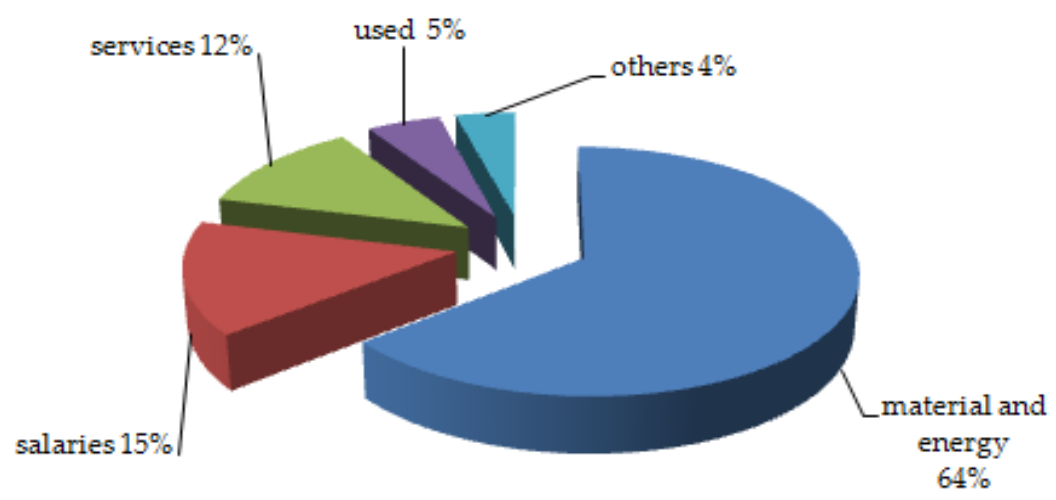

Figure 3. The share of energy costs in the steel production process.

Nowadays, changes in investment policy in the steel sector are based on the substitution of electricity, e.g., chemical energy and furnace heat recovery. This technology is popular in steel production because it is based on secondary raw materials (scrap) and not on natural ones. The entire steel industry in Poland is based on two technologies: electric arc furnace (EAF) and basic oxygen furnace (BOF) [56]. The increase in the share of EAF technology in steel production in Poland is shown in Figure 4. Both key technologies have almost the same share of total steel production in recent years. The steel industry is energy intensive. Investments in the industry concern both technologies, which together constitute 100\% of the steel produced in Poland since 2002.

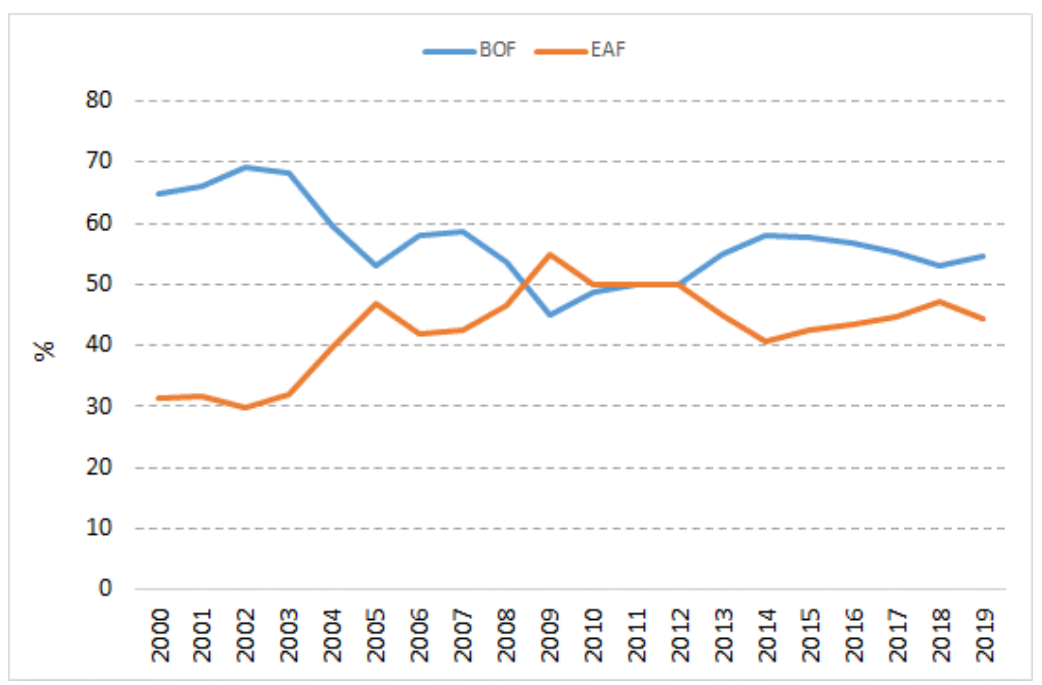

Figure 4. The share of electric arc furnace (EAF) and basic oxygen furnace (BOF) in total steel production in Poland.

At present, the world is dominated by an orientation towards the production of steel in micro-plants, especially in countries where the volume of steel production is not significant in the global market. 
Until 2002, open-hearth furnace (OHF) technology was also used in Poland. Figure 5 presents the trends in steel production processes in Poland in the period from 2000 to 2019. After 2010, a decrease in leaps in the technological trends is noted [54].

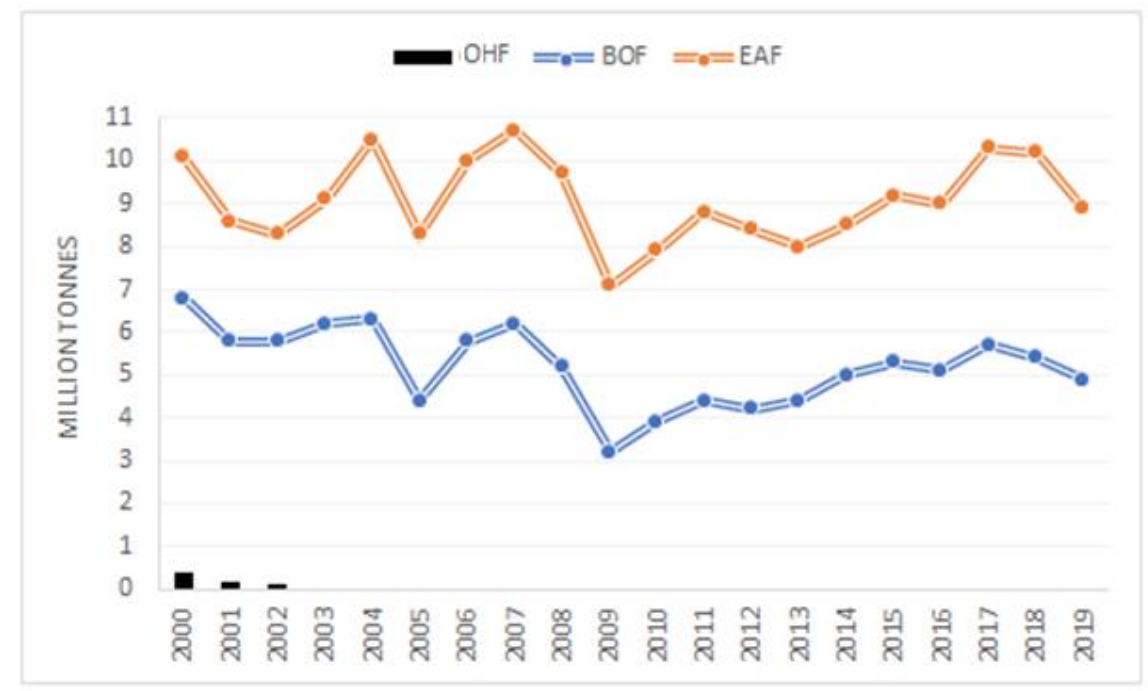

Figure 5. Trends in steel production processes in the Polish steel industry.

According to the forecast presented by the Statistical Agency of the Ministry of Energy Information Administration (EIA), there will be an increase in energy consumption from all sources by 2040 . During this period, fossil fuels will still provide the majority of the energy consumed in the world (almost 80\%). The EIA forecasts that the consumption of energy from renewable (unconventional) sources will grow by $2.5 \%$ annually [57].

A significant part of the total energy consumed in Polish industry is used for steel production. The remaining energy is used mainly for steel processing and other activities such as machining. Data from recent years show a decrease in energy consumption in the Polish steel industry along with the technological progress recorded during this period.

In the steel industry in Poland, the trend in energy consumption is declining, and takes the form of a polynomial function (1), with a high matching $\left(R^{2}=0.9584\right)$ :

$$
y=0.0007 x^{2}-0.0212 x+0.3609
$$

After 2010, as steel production volumes have stabilized (Figure 6), energy consumption (intensity) has also stabilized but it is still very high.

To verify the study hypotheses, data on (discounted and actual) investment values and energy consumption per 1 tonne of steel production in Poland in the period 2000-2019 were used. The statistical data used in Table 1 on energy consumption by the steel industry in Poland comes from the Polish Steel Association in Katowice, Poland and the Central Statistical Office.

In the conducted t-Student test, a value equal to 0.3948 was obtained, which is greater than the assumed level of significance of 0.05 . Therefore, from the correlation studies of the two variables, it follows that there is an insignificant positive correlation between investments and energy consumption. In the case under consideration, the correlation between investments and energy consumption was weak, therefore stronger correlations were sought by introducing a delayed response to investments into the calculations. Due to the inertia of the effects of investment in new technologies connected with Industry 4.0 and their impact on possible energy consumption per one tonne of steel produced, several models of correlation up to and including a fourth delay were examined. The simulations show that the strongest, and at the same time, the most significant correlation is between the investment and the decrease in energy consumption per one tonne after 3 years from the time the investment was made. 
Therefore, it can be seen that the current year's investments may have a significant effect on reducing energy consumption only 3 years after their introduction. The value of the correlation is then equal to $r=-0.50963511$. A " $p$ " value equal to 0.0366 was obtained in the correlation test, which is lower than the assumed significance level of 0.05 , so the assumption of no significant correlation is rejected (Figure 7).

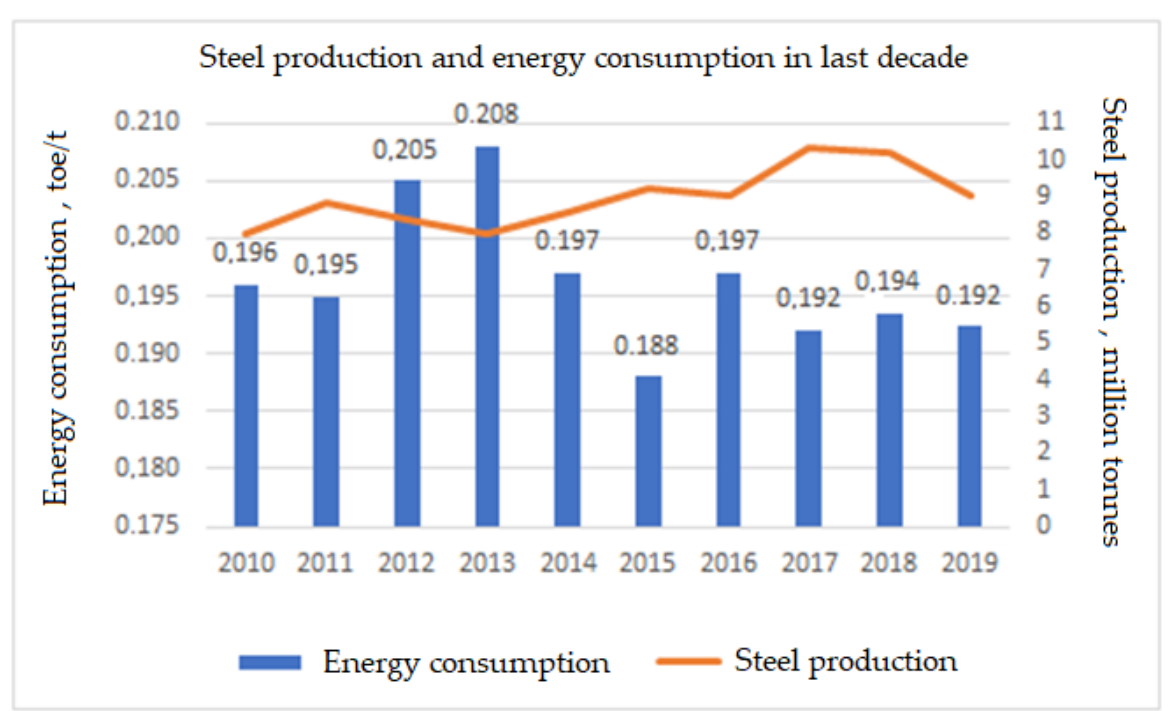

Figure 6. Energy consumption (intensity) and steel production in 2010-2019.

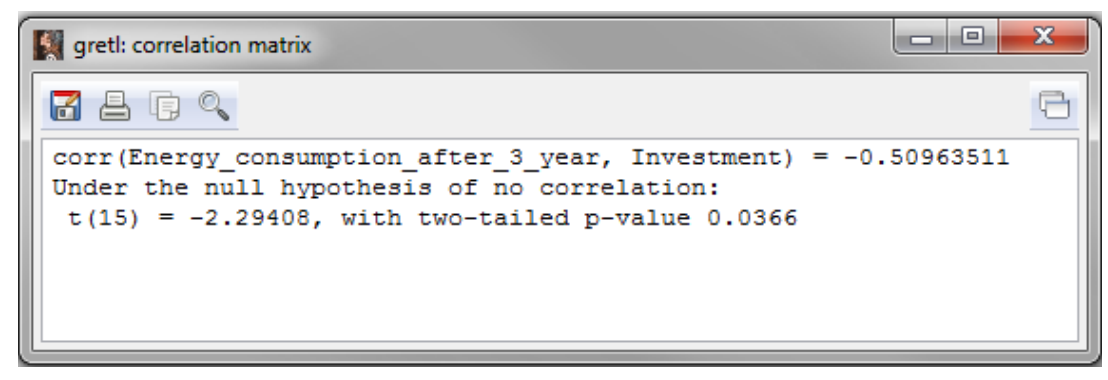

Figure 7. Correlation value for both tested variables and a 3-year energy consumption variable.

Figure 8 presents a correlation graph for both variables for the period 2003-2019, taking into account the 3 years of inertia of the investment effects.

On the basis of the results of the calculations, it can be concluded that increasing investment in new technologies connected with Industry 4.0 contributes to reducing energy consumption per one tonne of steel produced. Since there is a relationship between the investment and energy consumption in the third year of steel production, an econometric model was built in which the relationship between the variables under consideration were estimated using the smallest squares method to look for a relationship between the delay in the investment and energy consumption. Since the adopted model has many delays in insignificant investments (with values of $p>0.05$ ), these were eliminated by means of stepwise regression until a model with significant variables was obtained (Figure 9). 


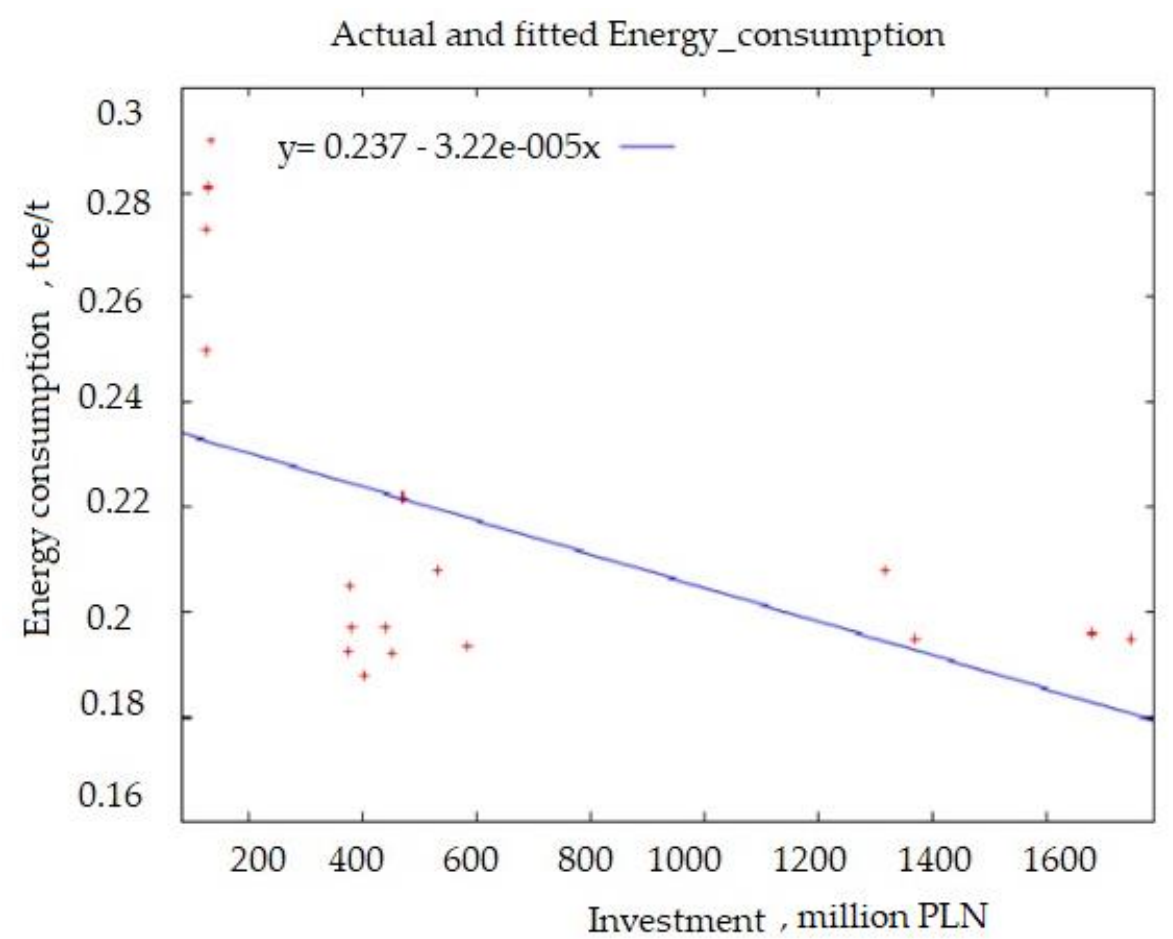

Figure 8. Correlation between energy consumption and investment for the period 2003-2019 taking into account the 3 years of inertia of investment effects.

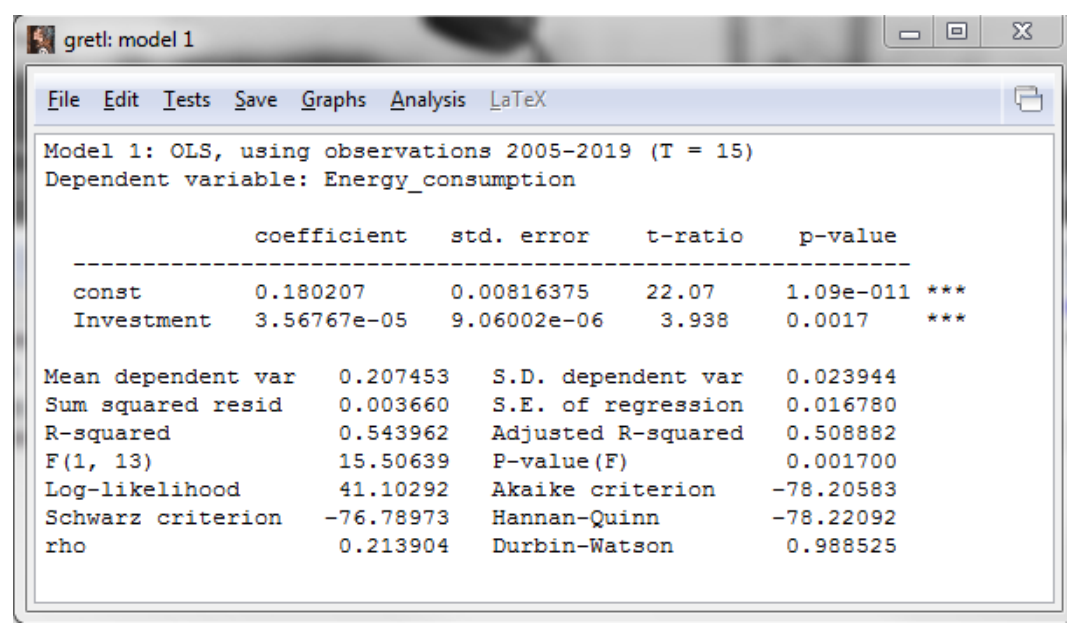

Figure 9. Econometric model.

In the model presented, significant relationships between non-delayed investments and energy consumption were identified, provided the trial period is shortened. The above model is based on data from 2005-2019 and not, as initially assumed, from the beginning of the 2000-2019 period. The model estimated from 2005-2019 has a 54.4\% fit and the model estimated on the basis of the original time period was only $4.05 \%$, i.e., slightly low. Figure 10 presents a graph of both variables for the adopted econometric model. The equation of the econometric model is as follows:

$$
\text { ^Energy_consum_per_1t }=0.180+3.57 \times 10^{-5} \times \text { Investments }
$$

for:

$\mathrm{t}-15$

determination factor $\mathrm{R}^{2}=0.544$

evaluation errors in parentheses $(0.00816)\left(9.06 \times 10^{-6}\right)$ 
Actual and fitted energy consumption

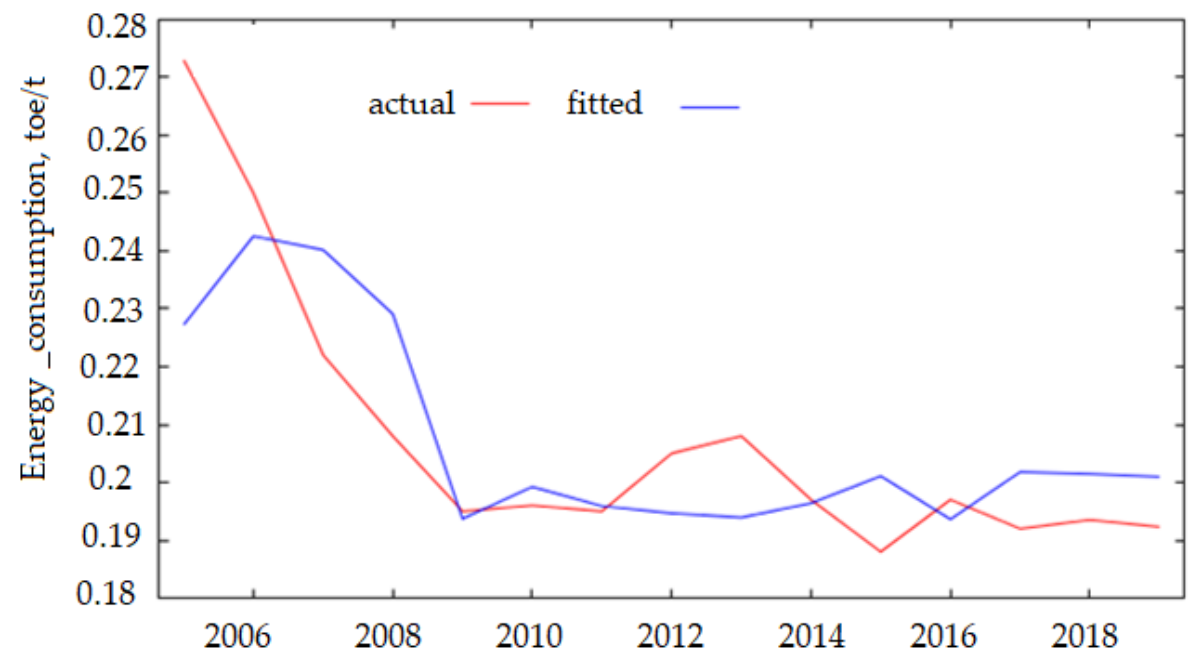

Figure 10. Theoretical (fitted) and empirical (actual) values of energy consumption in the examined time period.

The fit of the model in the form of a determining factor of $54.4 \%$ can be considered as sufficient. Variable investments are statistically significant, which proves that investments affect energy consumption in the steel production process. In the considered case, the average absolute percentage error (MAPE) is only 5.02\%, which means that the theoretical values of the model slightly deviate from the real values, thus its matching should be considered sufficient.

\section{Discussion}

Research has focused on the steel sector because it is the most energy-intensive industrial sector in Poland and significant investments and restructuring have recently taken place in this sector. The investments are aimed at reducing energy demand and environmental pollution. The key investments involve significant changes in the use of new, less energy-intensive production technologies. By the end of the 1990s, the technology for smelting steel in open-hearth furnaces was phased out for economic and environmental reasons (the smelting of steel by OHFs ceased in 2002). Currently, steel production is carried out using integrated processes (BOF and EAF). Steel producers in Poland belong to strong international capital groups [54] and have a significant market share (the largest steel mills produce $70 \%$ of the annual domestic steel production). Today, the steel industry is a key industry sector in the Polish economy (the share of value added is about $3 \%$ per year). The average annual volume of steel production in Poland is just over nine million tonnes [38].

Similar research on reducing energy in steel production through the use of new technologies includes studies on direct reduced iron (DRI) technologies [55]. The benefits of and perspectives on the development of DRI technologies were the subject of research and analysis in [56-58]. Energy consumption is a specific feature of each steel mill and country. Energy saving in the steel industry is closely related to the technology used, the size of the plant, the quality of the raw materials, the price of energy and other fuels (gas, coal), the location of the steel mill relative to the supply of energy and raw materials, the availability of raw materials, legal restrictions on environmental protection, etc. These components result in differences in energy management in individual countries but are a useful for building theoretical comparative models [42] within regions or other sectors in one country (by using data envelopment analysis (DEA) or most often [59], within the processes and technologies of steel production in a given country [43].

Poland is ranked 19th in the world steel production—based on World Steel [60]. Because the steel production sector constitutes a significant share of the Polish economy, further investments are needed to reduce the negative impact of production on the environment and energy consumption. 
Current research pays special attention to energy efficiency, which is particularly important for production costs and environmental protection, as well as $\mathrm{CO}_{2}$ emissions.

For example, an important innovation was the automation of the blast furnace process, that is, precise control of pig iron melting, which enables the achievement of higher technical and economic parameters.

At present, the most important investments in the steel sector include withdrawal of OHF technology, automation of production, continuous steel casting system, automation of the blast furnace, automation of warehouses, and a reduction in employment. Apart from the technical possibilities of obtaining added value by reducing energy consumption, a very important aspect is to encourage companies to improve organizational conditions to function in the new conditions of the Industry 4.0. This requires defining some of the assumptions underlying investment policies for the steel production sector.

In the Polish steel industry, the automation of steel production intensified after 2005. The majority of investments were in fixed assets ( $70 \%$ of the total value of investments), the remaining investments were the purchase of rights (patents, licenses) to the acquired technologies or capital investments. The largest steel mills in Poland made the largest long-term investments in the period under review.

The key investments include the automation of steel melting technology, automation of continuous steel casting lines and automation of product rolling process. Along with the automation of the technology, expenditure on computer aided manufacturing (CAM) systems increased. Automation of the continuous steel casting line resulted in unmanned service on selected production sections (e.g., $200 \mathrm{~m}$ of the production line without direct human labor). In the analyzed period, the number of manual workers in the steel industry in Poland decreased and the number of workers in services and IT (information technology) increased.

Investment in the automation of steel production in Poland brought steel mills closer to Industry 4.0 (that is, it created the conditions for investment in the Industry 4.0 technologies). In the second decade of the 21st century, steel mills in Poland increased expenditure on investments related to the purchase of sensors mounted on selected, key technological lines (cells, sockets, systems) of steel production. Robots have also been installed to replace humans when performing particularly dangerous activities during pig iron melting (e.g., taking material samples to the next step of steel processing). Data that are obtained from devices, e.g., rolling mills, are used to shorten setup time (single minute exchange of die (SMED). The entire production system has been redirected to the realization of individual customer orders (customization). Customers have the opportunity to participate in the design of the final product to a certain extent, e.g., the choice of protective coating on flat products. Other innovations that are bringing steel mills in Poland closer to Industry 4.0 include the visualization of the entire production process using modern imaging methods and information transmission in real-time.

Industry 4.0 relies on energy-efficient technologies and emerging trends in the integration of intelligent design, manufacturing and services throughout the product life cycle and throughout the industrial value chain are conducive to improving energy efficiency. Therefore, today's steel companies, in addition to looking for new technologies related to Industry 4.0 that directly reduce energy consumption through the technological process, are focusing their attention on the application of Industry 4.0 technology, which will indirectly reduce energy consumption. The implementation of the Industry 4.0 concept will enable steel companies to be part of integrated cyber-physical system (CPS) networks, which means creating a network of raw material suppliers, manufacturers, customers, logistics companies and customer-oriented energy suppliers. These solutions will allow the creation of new business models by means of intelligent systems and smart value networks. Another important aspect of investment policy is the use of new maintenance technologies. It is estimated that maintenance constitutes as much as $60-75 \%$ of the total life cycle costs of the production system. Proper maintenance and monitoring of the condition of production lines, machines and devices reduces the number of failures, and thus ensures continuity of production. The application of the Industry 4.0 concept allows collecting more real-time data from sensors installed in production machines and equipment. 
The modernization of the machinery park, and the installation of sensors, control and monitor devices, etc., will contribute to savings in energy consumption. This also has an impact on energy savings as the machines can maintain an optimal configuration through appropriate maintenance processes [34,61-63]. Repeated failures lead to increased energy consumption of the machines, therefore, a maintenance and prevention strategy based on historical analyses and forecasts is needed in factories. Further investment in the automation and robotization of steel production reduces the negative environmental impact of steel mills, e.g., in terms of using diversified energy sources in the production process. Polish steel mills should now focus on the rational use of energy, including energy used to power machinery (equipment).

The correlation study between investment and energy consumption per one tonne of steel produced reported in this article showed that there is a slight, positive correlation between investment and energy consumption. In this case, the correlation between investments and energy consumption was weak, so stronger correlations were sought by introducing a delayed response to investments into the calculations. Due to the delay in the effects of investment in new technologies related to Industry 4.0 and their impact on the possible energy consumption per one tonne of steel produced, it was proved that the strongest and the most significant correlation occurs between the investment and a decrease in energy consumption 3 years after the investment. The presented econometric model can be used to forecast the amount of energy consumption at a given investment volume in a given year in the future. Energy efficiency in the industrial sector translates directly into production costs, and thus into profits, product and company competitiveness on the global market. The research shows that in the case under consideration, an increase in investment by PLN 1 million results in a decrease in energy consumption per tonne of steel of 0.0000357 toe/t with an average error of 0.000009 toe/t. This confirms the validity of the hypothesis. At the same time, correlation analysis shows the inertia (delay) in the impact of investments in new technologies (including technologies connected with Industry 4.0) on the reduction in energy consumption to produce one tonne of steel. This means that the investment policy aimed at the efficient use of energy and implementation of subsequent solutions related to the Fourth Industrial Revolution is correct.

On the basis of the calculations carried out, it can be concluded that increasing investment in new technologies related to Industry 4.0 contributes to reducing energy consumption per tonne of steel produced. Since there is a link between the investment and energy consumption in the third year of steel production, an econometric model was constructed in which the relationship between the variables was estimated using the least squares method to find a link between the delay in the investment and energy consumption. The econometric model can be used to forecast the amount of energy consumption for a given amount of investment in a given year in the future.

Industry 4.0 in Poland is still a new concept. It is difficult to predict whether changes or innovations that are implemented gradually or selectively in different areas of the economy (industry) will translate into energy efficiency. The examples (areas of change) cited above are considered to be key in the development of Industry 4.0.

\section{Conclusions}

The results of this study confirm the hypothesis that there is a link between investment in new technologies and energy efficiency in steel production. On the basis of the research carried out, it can be concluded that a further increase in investment in the steel sector will result in a reduction in energy consumption per tonne of steel produced. The basic tool for assessing the correlation between the phenomena under investigation, the Pearson's correlation coefficient, assumes a negative relationship, which means that the increase in investment in the sector under investigation will lead to a decrease in energy consumption in steel production. The proposed econometric model is an example of a possible relationship between electricity consumption per tonne of steel and the amount of investment expenditure to implement Industry 4.0 strategies.

Steel companies should focus on networked forms of cooperation in cyber-physical intelligent resource systems that communicate throughout the supply chain. Experience to date with the 
implementation of the Industry 4.0 concept shows significant potential for gains in energy efficiency and improvements in productivity. To this end, steel producers should strive for full automation and greater flexibility of production processes. This will reduce the burdensome impact of the production process on employees and the environment, and also shorten production time, better match market needs and increase process efficiency while reducing energy consumption. Automation will mean investment in the field of industrial robots, together with the infrastructure required for them, and the purchase of appropriate control software. This includes the incorporation and integration of different services at different levels, such as IoT, CPS, cloud computing and fog computing. The IoT enables data to be collected in applications, leading to more accurate readings of equipment and production processes, detecting the causes of performance changes and sources of failure, which saves time, and leads to efficient use of human and machine resources, thus reducing production costs. On the basis of the collected data, it is possible to assess the effects of the decisions made in real-time, but also to perform predictive maintenance.

The main contribution of the work is to prove the impact of investment in new technologies on the reduction of energy consumption in the steel production process. On this basis, we can conclude that new investment in technologies related to Industry 4.0 in the steel sector in the future will bring about a reduction in the energy consumed to produce one tonne of steel. The aim of further research is to develop investment policies and business models for the steel sector that take into account networked forms of cooperation and that focus on improving energy efficiency throughout the value chain in the era Industry 4.0.

Author Contributions: The main contributions of the authors are as follows: conceptualization, S.G., S.S. and B.G.; methodology, S.G., S.S. and B.G.; software, S.S.; validation, S.G., S.S., R.W. and B.G.; formal analysis, S.G., S.S., R.W. and B.G.; investigation, S.G., S.S., R.W. and B.G.; resources, S.G., S.S., R.W. and B.G.; data curation, S.G., S.S., R.W. and B.G.; writing—original draft preparation, B.G., S.S., S.G.; writing-review and editing, S.G., S.S., R.W. and B.G.; visualization, B.G., S.S.; supervision, S.G., S.S., R.W. and B.G.; funding acquisition, R.W. All authors have read and agreed to the published version of the manuscript.

Funding: This research received no external funding.

Conflicts of Interest: The authors declare no conflict of interest.

\section{References}

1. Ki-Hoon, L. Drivers and Barriers to Energy Efficiency Management for Sustainable Development. Sustain. Dev. 2014, 23, 16-25. [CrossRef]

2. Florens, F.; Rübbelke, D.; Vögele, S. An analysis of the economic determinants of energy efficiency in the European iron and steel industry. J. Clean. Prod. 2015, 104, 250-263. [CrossRef]

3. Grabowska, S.; Gajdzik, B.; Saniuk, S. The role and impact of industry 4.0 on business models. In Sustainable Logistics and Production in Industry 4.0. EcoProduction (Environmental Issues in Logistics and Manufacturing); Grzybowska, K., Awasthi, A., Sawhney, R., Eds.; Springer: Cham, Germany, 2020. [CrossRef]

4. Saniuk, S.; Grabowska, S.; Gajdzik, B. Social expectations and market changes in the context of developing the industry 4.0 concept. Sustainability 2020, 12, 1362. [CrossRef]

5. Pilloni, V. How data will transform industrial processes: Crowdsensing, crowdsourcing and big data as pillars of industry 4.0. Future Internet 2018, 10, 24. [CrossRef]

6. Stock, T.; Seliger, G. Opportunities of sustainable manufacturing in industry 4.0. Procedia CIRP 2016, 40, 536-541. [CrossRef]

7. Longo, F.; Nicoletti, L.; Padovano, A. Smart operators in industry 4.0: A human-centered approach to enhance operators' capabilities and competencies within the new smart factory contex. Comput. Ind. Eng. 2017, 113, 144-159. [CrossRef]

8. Christoph, N.; Hirzel, S.; Arens, M. Industry 4.0 in the European Iron and Steel Industry: Towards an Overview of Implementations and Perspectives; Fraunhofer Institute for Systems and Innovation Research ISI: Karlsruhe, Germany, 2018. Available online: https:/www.isi.fraunhofer.de/content/dam/isi/dokumente/cce/2018/ Industry-4-0-Implementation-and-Perspectives_Steel-Industry_Working\%20document.pdf (accessed on 20 March 2020). 
9. Lasi, H.; Fettke, P.; Kemper, H.-G.; Feld, T.; Hoffmann, M. Industry 4.0. Bus. Inf. Syst. Eng. 2014, 6, $239-242$. [CrossRef]

10. Santos, K.; Loures, E.; Piechnicki, F.; Canciglieri, O. Opportunities assessment of product development process in industry 4.0. Procedia Manuf. 2017, 11, 1358-1365. [CrossRef]

11. Rüßmann, M.; Lorenz, M.; Gerbert, P.; Waldner, M.; Justus, J.; Engel, P.; Harnisch, M. Industry 4.0: The Future of Productivity and Growth in Manufacturing Industries. Available online: www.inovasyon.org/pdf/bcg. perspectives_Industry.4.0_2015.pdf (accessed on 6 January 2020).

12. Fatorachian, H.; Kazemi, H. A critical investigation of Industry 4.0 in manufacturing: Theoretical operationalisation framework. J. Prod. Plan. Control Manag. Oper. 2018, 29, 633-644. [CrossRef]

13. Erboz, G. How to Define Industry 4.0: The Main Pillars of Industry 4.0. 2017. Available online: https://www.researchgate.net/publication/326557388_How_To_Define_Industry_40_Main_Pillars_ Of_Industry_40 (accessed on 28 February 2020).

14. Saniuk, S.; Saniuk, A.; Cagáňová, D. Cyber industry networks as an environment of the Industry 4.0 implementation. Wirel. Netw. 2019, 1-7. [CrossRef]

15. Gajdzik, B. The road of Polish steelworks towards market success-Changes after restructuring process. Metalurgija 2013, 52, 421-424.

16. Johansson, M. Improved energy efficiency within the Swedish steel industry-The importance of energy management and networking. Energy Effic. 2015, 8, 713-744. [CrossRef]

17. Soepardi, A.; Thollander, P. Analysis of relationships among organizational barriers to energy efficiency improvement: A case study in Indonesia's steel industry. Sustainability 2018, 10, 216. [CrossRef]

18. Kozłowski, J.; Sika, R.; Górski, F.; Ciszak, O. Modeling of Foundry Processes in the Era of Industry 4.0; Springer: Berlin/Heidelberg, Germany, 2019; pp. 62-71.

19. Dybowski, B.; Perzyk, M.; Kozlowski, J. Introducing Industry 4.0 in a die casting foundry. In Proceedings of the 73rd World Foundry Congress, Creative Foundry, WFC 2018, Krakow, Poland, 23-27 September 2018; pp. 401-402.

20. Vehreschild, M. GIFA, METEC and Co.: Foundry solutions for automobile manufacture and Industry. Stahl Eisen 2019, 139, 44-45.

21. Liszka, K.; Klimkiewicz, K.; Malinowski, P. Polish foundry engineer with regard to changes carried by the industry 4.0. Arch. Foundry Eng. 2019, 19, 103-108.

22. Gilson, D. Industry 4.0 process control and traceability for the foundry industry. In Proceedings of the 73rd World Foundry Congress, Creative foundry, WFC 2018, Krakow, Poland, 23-27 September 2018; pp. 591-592.

23. Pandya, Y.; Suchy, J.; Nagaraj, S.V. Adaptive product manufacturing technique for foundry industry using IoT technology: An industry 4.0 initiative. In Proceedings of the 73rd World Foundry Congress, Creative Foundry, WFC 2018, Krakow, Poland, 23-27 September 2018; pp. 161-162.

24. Lewis, M.; Jeffs, P. Industry 4.0 and what it means to the foundry industry. Foundry Trade J. Int. 2017, 191, 12-23.

25. Saxena, P.; Papanikolaou, M.; Pagone, E.; Salonitis, K.; Jolly, M.R. Digital manufacturing for foundries 4.0. In Light Metals; Springer: Cham, Switzerland, 2020; pp. 1019-1025.

26. Kolloch, M.; Reck, F. Innovation networks in the German energy industry: An empirical analysis of inter-organizational knowledge transfer. Int. J. Energy Sect. Manag. 2017, 11, 268-294. [CrossRef]

27. Mohamed, N.; Al-Jaroodi, J.; Lazarova-Molnar, S. Leveraging the capabilities of industry 4.0 for improving energy efficiency in smart factories. IEEE Access 2019, 7, 18008-180020. [CrossRef]

28. Helo, P.; Hao, Y. Cloud manufacturing system for sheet metal processing. Prod. Plan. Control 2017, $28,524-537$. [CrossRef]

29. Ghiasi, M.; Esmaeilnamazi, S.; Ghiasi, R.; Fathi, M. Role of renewable energy sources in evaluating technical and economic efficiency of power quality. Technol. Econ. Smart Grids Sustain. Energy 2020, 5, 1. [CrossRef]

30. Sung, S.; Jung, W. Economic competitiveness evaluation of the energy sources: Comparison between a financial model and levelized cost of electricity analysis. Energies 2019, 12, 4101. [CrossRef]

31. Sola, A.V.H.; Mota, C.M.M. Influencing factors on energy management in industries. Renew. Sustain. Energy Rev. 2020, 120, 109672. [CrossRef]

32. Dorsey-Palmateer, R.; Niu, B. The effect of carbon taxation on cross-border competition and energy efficiency investments. Energy Econ. 2020, 85, 104602. [CrossRef] 
33. Wu, J.; Yang, Z.; Hu, X.; Wang, H.; Huang, J. Exploring driving forces of sustainable development of China's new energy vehicle industry: An analysis from the perspective of an innovation ecosystem. Sustainability 2018, 10, 4827. [CrossRef]

34. Lee, D.; Cheng, C. Energy savings by energy management systems: A review. Renew. Sustain. Energy Rev. 2016, 56, 760-777. [CrossRef]

35. Perzyk, M.; Dybowski, B.; Kozłowski, J. Introducing advanced data analytics in perspective of industry 4.0 in a die casting foundry. Arch. Foundry Eng. 2019, 19, 53-57.

36. Grobler, F.; Minnitt, R. The increasing role of direct reduced iron in global steelmaking. J. S. Afr. Inst. Min. Metall. 1999, 2, 111-116. Available online: http://www.hannansreward.com/reports/120964-990304Increasing-iron-role.pdf (accessed on 15 April 2020).

37. Gajdzik, B.; Gawlik, R.; Skoczypiec, S. Forecasting-Scenario-Heuristic method proposal for assessment of feasibility of steel production scenarios in Poland-Managerial implications for production engineering. Arch. Civil Mech. Eng. 2018, 18, 1651-1660. [CrossRef]

38. Gajdzik, B. The predictive scenario analysis in a business model: Variants of possible steel production trajectories and efficiency in Poland. In Strategic Performance Management. Management Science-Theory and Applications. New Concepts and Contermproray Trends; Jabłoński, M., Ed.; Nova Science Publishers Inc.: New York, NY, USA, 2017; Chapter 15; pp. 235-252. ISBN 978-1-53612-682-2 e-book.

39. Cruz, A.B.; Sousa, A.; Cardoso, Â.; Valente, B.; Reis, A. Smart data visualisation as a stepping stone for industry 4.0-A case study in investment casting industry. Adv. Intell. Syst. Comput. 2020, 1092, 657-668.

40. Jonek-Kowalska, I. Long-term analysis of the effects of production management in coal mining in Poland. Energies 2019, 12, 3146. [CrossRef]

41. Jonek-Kowalska, I. Method for assessing the development of underground hard coal mines on a regional basis: The concept of measurement and research results. Energies 2018, 11, 1370. [CrossRef]

42. Fruehan, R.; Fortini, O.; Paxton, W.; Brindle, R. Theoretical Minimum Energies to Produce Steel (for Selected Conditions); Energetics, Inc.: Columbia, MD, USA, 2000.

43. Example: Energy Use in Steel Industry in US: N. Materno Energy Use in US Steel Manufacturing December 4, 2016 Submitted as Coursework for PH240. Stanford University: Stanford, CA, USA, 2016. Available online: http://large.stanford.edu/courses/2016/ph240/martelaro1/ (accessed on 15 April 2020).

44. Łukaszewska, H. Selected issues in innovation in the energy industry. The case of Poland. Int. J. Manag. Econ. 2016, 50, 100-112. [CrossRef]

45. Segura, E.; Morales, R.; Somolinos, J.A. Increasing the competitiveness of tidal systems by means of the improvement of installation and maintenance maneuvers in first generation tidal energy converters-An economic argumentation. Energies 2019, 12, 2464. [CrossRef]

46. Gregg, J.S.; Nyborg, S.; Hansen, M.; Schwanitz, V.J.; Wierling, A.; Zeiss, J.P.; Delvaux, S.; Saenz, V.; Polo-Alvarez, L.; Candelise Ch Gilcrease, W.; et al. Collective action and social innovation in the energy sector: A mobilization model perspective. Energies 2020, 13, 651. [CrossRef]

47. Pan, X.; Liu, H.; Huan, J.; Sui, Y.; Hong, H. Allocation model of carbon emission permits for the electric power industry with a combination subjective and objective weighting approach. Energies 2020, 13, 706. [CrossRef]

48. Sueyoshi, T.; Goto, M. Performance assessment of Japanese electric power industry: DEA measurement with future impreciseness. Energies 2020, 13, 490. [CrossRef]

49. Czosnyka, M.; Wnukowska, B.; Karbowa, K. Energy efficiency as a base of the energy economy in a modern industrial plants. Prog. Appl. Electr. Eng. PAEE 2018, 8441086. [CrossRef]

50. Hong, Y. Probability and Statistics for Economists; World Scientific: Singapore, 2017.

51. Keller, G. Statistics for Management and Economics; Cenage Learning: Boston, MA, USA, 2017.

52. Peck, R.; Short, T. Statistics. Learning from Data; Cengage: Boston, MA, USA, 2018.

53. Mixon, J. GRETL: An econometrics package for teaching and research. Manag. Financ. 2009, 36, 71-81. [CrossRef]

54. Borowiecki, R.; Wysłocka, E. Możliwości i kierunki optymalizacji kosztów produkcji w polskim hutnictwie. Zesz. Nauk. Uniw. Ekon. Krakowie 2003, 618, 16-33.

55. Zdonek, B.; Mazur, A.; Szypuła, I.; Stefaniak, A. Kierunki optymalizacji kosztów wsadowych, eksploatacyjnych i energii w procesie wytwarzania stali, Gliwice. Pr. Inst. Metal. Żelaza 2000, 2, 31.

56. Gajdzik, B. Prognostic modeling of total steel production and according to production technology in Poland. Metalurgija 2017, 56, 241-244. 
57. Annual Energy Review 2010; EIA: Washington, DC, USA, 2010; Volume 38.

58. 2018 World Direct Reduction Statistics (PDF); Midrex Technologies: Lebanon, New Jersey, USA, 2019.

59. Haider, H. Reducing the energy consumption of Indian iron and steel industry through enhancing energy efficiency: Role of regional coordination. J. Public Aff. 2020. [CrossRef]

60. World Steel in Figures 2019, Published: World Steel Association. Available online: https://www.worldsteel. org/media-centre/press-releases/2019/world-steel-in-figures-2019.html (accessed on 20 March 2020).

61. Efthymiou, K.; Papakostas, N.; Mourtzis, D.; Chryssolouris, G. On a predictive maintenance platform for production systems. Procedia CIRP 2012, 3, 221-226. [CrossRef]

62. Hock Ang, J.; Goh, C.; Saldivar, A.; Li, Y. Energy-Efficient through-Life Smart Design, Manufacturing and Operation of Ships in an Industry 4.0 Environment. Energies 2017, 10, 610. [CrossRef]

63. Kantor, M.; Fowler, A.; Elkamel, A. Optimized production of hydrogen in an eco-park network accounting for life-cycle emission and profit. Int. J. Hydrogen Energy 2012, 37, 5347-5359. [CrossRef]

(C) 2020 by the authors. Licensee MDPI, Basel, Switzerland. This article is an open access article distributed under the terms and conditions of the Creative Commons Attribution (CC BY) license (http://creativecommons.org/licenses/by/4.0/). 